Шпакович О.М. - доктор юридичних наук, профресор, професор кафедри порівняльного і європейського права Інституту міжнародних відносин Київського національного університету імені Тараса Шевченка, м. Київ

ORCID: https://orcid.org/0000-0002-1080-4817;

Каграманян Д. Д. - студент 4-го курсу відділення «міжнародне право» Інституту міжнародних відносин Київського національного університету імені Тараса Шевченка, м. Київ

ORCID: https://orcid.org/0000-0002-5253-128X

\title{
Внутрішнє право міжнародних організацій
}

Мета статті полягає в аналізі наукових досліджень щодо внутрішнього права міжнародних організацій та визначенні поняття, юридичної природи, місия внутрішнього права міжнародних організацій в міжнародному праві на прикладі внутрішнього права ЮНЕСКО. Методологічну основу дослідження становлять порівняльно-правовий, системний та історичний методи наукового пізнання. Наукова новизна. Автори досліджують і зіставляють ключові питання та доктринальні підходи до визначення поняття юридичної природи та інших питань стосовно внутрішнього права міжнародних організацій, демонструючи особливості й тонкощі такої проблематики на прикладі Організації Об'єднаних Націй з питань освіти, науки та культури (ЮНЕСКО). Висновки. Висвітливши ключові питання в контексті розуміння поняття та сутності такого френомену, як внутрішне право міжнародної організації, можна дійти таких висновків: внутрішнє право міжнародних організацій слід розглядати як систему юридичних норм, що приймають органи міжнародної організації на підставі їі статуту й виражають ії волю, які покликані регулювати внутрішні відносини організації для забезпечення ї̈ ефективного фрункціонування. Попри безліч суперечок навколо питання щодо місця внутрішнього права організацій в системі міжнародного права, внутрішнє право не $\epsilon$ частиною внутрішньодержавного чи міжнародного публічного права, а є частиною міжнародного права в широкому сенсі цього поняття. Не погоджуємося з науковцями, які розглядають внутрішнє право у вузькому сенсі та не відносять установчі акти до його джерел.

Ключові слова: міжнародні організації; внутрішнє право міжнародних організацій; внутрішнє право ЮНЕСКО; правила процедури ЮНЕСКО; право міжнародних організацій.

\section{Вступ}

У межах розвитку сучасного міжнародного права важливу роль відіграє такий актор, як міжнародні організації. Міжнародні організації $€$ суб'єктами міжнародного права та посідають важливе місце на світовій арені. 3 огляду на зазначене вбачається за потрібне розуміння механізму функціонування такого унікального за своєю природою феномену, що $€$ предметом численних дискусій у правовій доктрині.

\section{Мета і завдання дослідження}

Мета статті полягає в аналізі наукових досліджень щодо предмета внутрішнього права міжнародних організацій та визначенні поняття юридичної природи, місця внутрішнього права міжнародних організацій в міжнародному праві на прикладі внутрішнього права ЮНЕСКО.

Чимало вітчизняних і західних фрахівців вивчали у своїх працях важливі питання досліджуваної тематики, зокрема: І. Деттер, Н. Камінська,

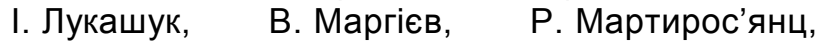
В. Моравецький, Г. Морозов, М. Поточний, Ю. Сарвіро, Г. Тункін, С. Черниченко, О. Шибаєва, О. Шпакович тощо.

Однак, попри велику кількість опусів як у вітчизняній, так і в західній науці, що переважно досліджують історію, розвиток, правотворчу діяльність, бракує єдиного бачення фрундаментальних принципів внутрішнього права міжнародних організацій і їх правової природи.

\section{Виклад основного матеріалу}

Історія існування та розвитку такого феномену, як міжнародні організації, бере свій початок ще з античних часів і досі триває. Саме еволюція міжнародних організацій як таких i породжує розширення кола питань, що належать до їх компетенції, та тим самим збільшує їх значущість для міжнародної спільноти. Уже в період існування адміністративних союзів (XIX ст.) постає логічне питання щодо інструментів врегулювання правовідносин, що виникають у межах міжнародних організацій. Саме правила, що виникли в період існування адміністративних союзів та регулювали їх внутрішнє функціонування, стали поштовхом до виникнення в доктрині такого поняття, як внутрішнє право міжнародних організацій. Проте офріційно фракт існування внутрішнього права міжнародних організацій було визнано лише 1929 року в рішенні Адміністративного трибуналу Ліги Націй, де трибунал зазначив, що застосував у постанові внутрішнє право співтовариства, сформульоване в правилах персоналу ("Tribunaladministratif", 1929). 
Науковці виокремили унікальну природу внутрішнього права міжнародних організацій, що відрізняється і від внутрішньодержавного, і від міжнародного права. Тогочасне розуміння термінів має відмінності від сучасного їх розуміння. Сукупність норм, пов'язаних 3 діяльністю персоналу організації та функціонуванням її органів і було визнано внутрішнім правом міжнародних організацій. Хоча це визначення об'єктивно не є таким, щоб повністю осягало та інтерпретувало природу й сутність внутрішнього права міжнародних організацій, але загальновизнаної дефініції в міжнародному праві наразі не існує, а доктрина пропонує велику кількість відмінних один від одного варіантів.

Наприклад, С.В.Черниченко вважає, що внутрішнє право міжнародних організацій - це «сукупність норм, що регулюють структуру, порядок здійснення функцій, взаємовідносин між внутрішніми підрозділами міжнародної організації, та також статус та функції її посадових осіб» (Chernichenko, 1971).

На думку польського юриста В. Моравецького, внутрішнє право міжнародних організацій - це «сукупність норм, що належать до внутрішнього функціонування міжнародних організацій» (Moravetskiy, 1976).

Дослідник Г.І. Морозов називає внутрішнім правом міжнародних організацій «норми, що регламентують структуру, компетенцію, фрункції органів та діяльність міжнародних організацій, що стосується режиму та трудових відносин різних категорій персоналу, вирішення майнових, фрінансових та інших проблем, та також, правила процедури органів, що відіграють важливу роль в підвищенні ефективності діяльності міжнародних організацій» (Morozov, 1972).

Було б франаберією зазначати, що ці визначення не є достовірними, але, на нашу думку, вони не позбавлені недоліків, оскільки не зазначено, ким ухвалено ці норми, не встановлено предмет їх регулювання, коло питань, яке вони охоплюють, ким та як забезпечено їх виконання.

Комплексне визначення внутрішнього права міжнародних організацій пропонує В. І. Маргієв, зазначаючи, що «внутрішнє право міжнародних організацій - це сукупність юридичних норм, які приймає та забезпечує міжнародна організація в особі її органів на підставі установчого акту, що виражають волю самої організації та регулюють відносини, які виникають у межах організації між іï внутрішніми підрозділами, між організацією та державами-членами, а також між організацією та iï службовцями, між посадовими особами й персоналом організації» (Margiev, 1999).

Отже, досить очевидною $€$ суперечлива природа внутрішнього права міжнародних організацій, на чому наголошує О. А. Шибаєва, зазначаючи, що, на відміну від сталої та консолідованої думки щодо предмета існування внутрішнього права міжнародних організацій як такого, питання про його юридичну природу, джерела та місце в системі міжнародного права залишаються відкритою площиною для дискусій (Shibaeva, \& Potochnyy, 1988). Саме відмінність поглядів учених на ці питання і є перепоною, але, як відомо, істина народжується в суперечках, тож, можливо, колись буде розроблено кодифіковану систему норм, що регулюють цей правопорядок і дають відповіді на всі зазначені питання.

Розбіжності починаються з питань, похідних від самого визначення внутрішнього права міжнародних організацій: які норми можна розуміти під цим поняттям. Умовно вчених, що вивчають це питання, можна поділити на дві групи:

1) ті, хто розуміє це в широкому сенсі та втілює в це поняття рішення органів міжнародної організації; норми, що містять установчі акти організації та угоди, які організація ухвалює 3 державами-членами;

2) ті, хто вбачає в цих нормах тільки ті, які приймають органи міжнародної організації, розглядаючи внутрішнє право міжнародних організацій в більш вузькому сенсі.

Проте й тут не існує єдиного узгодженого погляду на це питання, оскільки деякі юристиміжнародники залучають до цього переліку будьякі рішення, які приймають органи міжнародної організації, навіть ті, що адресовані державам, і регулюють безпосередньо їхню поведінку. Основним аргументом на підтримку цього погляду $\epsilon$ те, що норми, які містять установчі договори, переважно не регулюють внутрішні питання, а лише інколи опосередковано їх зачіпають, уповноважуючи організацію самостійно приймати норми внутрішнього права.

Постає питання: як можна керуватися такою логікою, коли йдеться про норми, які містяться в установчих актах, та водночас розглядати рішення органів міжнародних організацій як єдине джерело внутрішнього права, адже не всі рішення органів міжнародних організацій покликані регулювати внутрішні відносини організації, та не всі вони $€$ нормативно-правовими актами. На нашу думку, попри кількість норм, що містяться в тому чи іншому нормативно-правовому акті, такий акт має розглядатися як джерело, вже за самого факту наявності в ньому норм, що регулюють відповідні відносини.

Такі судження висвітлено в працях багатьох дослідників сучасного міжнародного права (Proniuk, 2010; Voitsikhovskyi, 2020; Kaminskaia, 2014; Shpakovych, \&Shalamberidze, 2020; Kaminska, Shpakovich, \&Demidenko, 2018).

Так, на переконання І. І. Лукашука, «статут міжнародної організації не в змозі врегулювати усі питання, пов'язані 3 діяльністю такої організації, тому вирішення великої кількості 
конкретних питань внутрішньої діяльності надається самій організації, органу. До таких питань слід відносити процедурні правила, правила, що регулюють діяльність персоналу тощо (Lukashuk, 2005). Тобто основним джерелом внутрішнього права міжнародних організацій дійсно є рішення її органів, але це не скасовує того фракту, що установчі договори також є джерелами.

Схвалює цю думку й О.А. Шибаєва стверджуючи, що внутрішнє право міжнародних організацій слід розглядати в широкій перспективі, оскільки очевидним $\epsilon$ те, що будь-яке внесення змін до статуту міжнародної організації одразу ж спричинить зміни у внутрішньому правопорядку організації загалом (Shybaeva, \& Potochnyy, 1988). 3 огляду на зазначене можна зробити висновок, що сутність полягає в корисливих цілях: основна функція установчого акту в контексті питання джерел внутрішнього права організації полягає в тому, щоб створити підґрунтя й тим самим утворити механізм, за яким надалі організація сама прийматиме норми, потрібні для досягнення ії цілей та ефективного функціонування.

Так, норми, що містяться в статуті міжнародної організації та регулюють ії внутрішнє право можна поділити на такі, що безпосередньо регулюють внутрішньо-організаційні відносини, як наприклад ст. IV.D.9(a) Статуту ЮHЕСКО: «Генеральная конфреренция собирается на очередные сессии раз в два года. Она может собраться на внеочередную сессию по своему решению, по решению Исполнительного сонета или по требованию не менее одной трети государств-членов»; та на такі, що мають загальний характер і слугують підставою для прийняття норм внутрішнього права самою організацією (ст. IV.D.10. Статуту ЮНЕСКO) ("Ustav Organizatsii Obedinennykh Natsiy", 1945; "Pravila protsedury Generalnoy Konferentsii", 2018; "Pravila protsedury Ispolnitelnogo Soveta", 2018).

Також В.І. Маргієв називає важливим у процесі визначення поняття внутрішнього права міжнародних організацій питання щодо того, які органи наділені правотворчими функціями. Можливість прийняття таких норм для головних органів організацій прямо передбачено установчим документом (Margiev, 1999). Так, наприклад ст. VII Статуту ЮНЕСКО уповноважує Генеральну Конференцію затверджувати правила процедури, створювати спеціальні й технічні комісії та інші допоміжні органи, необхідні для досягнення ії цілей. Допоміжні органи, в свою чергу, уповноважені на правотворчу діяльність головними органами, що їх засновують. Звичайно, існує певна ієрархія органів міжнародних організацій, тож і роль головних і допоміжних органів у правотворчих процесах не ототожнюється.
Внутрішнє право міжнародних організацій відносно нова галузь проведення доктринальних досліджень, тож неузгоджених питань набагато більше, ніж може здаватися на перший погляд. Так, предметом дискусії $€$ питання юридичної природи норм, що регулюють внутрішній правопорядок організації.

Наразі в доктрині міжнародного права існує три концепції щодо визначення особливостей юридичної природи норм внутрішнього права міжнародних організацій:

1) норми внутрішнього права міжнародних організацій належать до норм міжнародного договірного права (міжнародного публічного права);

2) норми внутрішнього права міжнародних організацій складають самостійний підрозділ норм;

3) норми внутрішнього права міжнародних організацій належать до норм міжнародного права в широкому сенсі цього поняття.

Можна знайти безліч авторитетних думок й опусів на підтримку кожного з підходів, оскільки цю проблематику досліджували такі юристиміжнародники, як:С. Амерасінх, Д. Анцелотті,
Н. В. Камінська,
І. І. Лукашук,
B. І. Мapriєв,

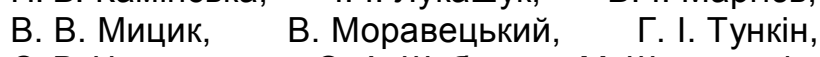
С. В. Черниченко, О.А. Шибаєва, М. Шоу та ін. Однак, щоб зробити висновки щодо того, який 3 підходів більше відповідає дійсності, треба зрозуміти їх сутність.

Прибічники першої концепції стверджують, що норми внутрішнього права міжнародних організацій належать до норм міжнародного договірного права, оскільки статут організації - результат узгодження волі держав. Безперечно, норми, що містяться в установчих актах, $€$ нормами договірного характеру, але, як зазначалося раніше, основним джерелом внутрішнього права міжнародних організацій $€$ рішення таких організацій. Вони, за глибоким переконанням автора, не є узгодженням волі держав, це є волею безпосередньо самої організації. Одного разу санкціонувавши існування організації та уповноваживши ії на прийняття рішень шляхом узгодження волі, держави-засновники створюють новий, самостійний суб'єкт міжнародного права. На підтримку цього погляду багато дослідників проводять аналогію 3 внутрішньодержавним правом, зазначаючи, що норми, які приймають міністерства на підставі конституції, не стають через це конституційними. Відповідно й рішення, що створюють органи організації, приймаються на підставі статуту організації, але не стають договірними нормами.

Згідно з другою концепцією, норми внутрішнього права міжнародних організацій складають самостійний підрозділ норм. 3 цього питання найбільш аргументованою, на думку автора, $є$ позиція В.І. Маргієва, який погоджується 3 
прибічниками цієї концепції тільки в тому, що норми внутрішнього права не $€$ частиною ані міжнародного публічного права, ані внутрішньодержавного права (Margiev, 1999). На нашу думку, внутрішнє право міжнародних організацій не може бути незалежною системою права як мінімум 3 двох причин:

1) по-перше, внутрішнє право організації вже за своєю природою не може бути повністю незалежним, оскільки існує на підставі установчого документа - міжнародного договору, що містить норми міжнародного публічного права;

2) по-друге, воно не може бути одночасно незалежним як від внутрішньодержавного, так і від міжнародного права. Будь-яка галузь може бути або частиною однієї 3 систем, або автономною галуззю в її складі.

Також В.ІІ. Маргієв зауважує, що такі норми $\epsilon$ «міжнародними, але не міждержавними в традиційному розумінні цього поняття» (Margiev, 1999).

Це твердження повністю передає унікальну природу внутрішнього права. Основна помилка прибічників концепції автономності полягає в тому, що вони ототожнюють держави та міжнародні організації як суб'єктів, та не розрізняють міжнародне право й міжнародне публічне право. Внутрішнє право міжнародних організацій може бути автономною складовою лише щодо міжнародного публічного права, яке таким чином входить до системи міжнародного права. Тобто внутрішнє право міжнародних організацій не може фрормувати повністю незалежну систему.

Згідно 3 третьою концепцією, норми внутрішнього права міжнародних організацій належать до норм міжнародного права в широкому сенсі цього поняття. Широке розуміння поняття «міжнародне право» містить міжнародне публічне право, міжнародне приватне право та право міжнародних організацій (Shpakovych, 2020). Дослідник Ю. Сарвіро зазначає, що «внутрішнє право міжнародних організацій являє собою комплексне явище, елементи якого мають різну юридичну природу, та регулює відносини не тільки між суб'єктами міжнародного публічного права (державами та міжнародними організаціями), але й відносини за участі фрізичних та юридичних осіб, отже, виходить за межі міжнародного публічного права» (Sarviro, 2009).

На підтримку цієї думки також є консультативний висновок Міжнародного Суду ООН від 23 жовтня 1956 року стосовно рішення Адміністративного трибуналу Міжнародної організації праціза скаргою МОП проти ЮНЕСКО. У консультативному рішенні зазначено: "The arguments, deduce from the sovereignty of States, which might have been in voked in favour of a restrictive interpretation of provisions governing the jurisdiction of a tribunal adjudicating between States are not relevantto a situation in which a tribunal is call eduponto adjudicate upon a complaintofan officia1against an international organization» ("ICJ Reports", 1956).

Тобто Суд чітко розмежовує Трибунали, покликані розглядати суперечки між державами, та Трибунал, покликаний виносити рішення за скаргою проти організації.

Також Суд акцентує на тому, що Адміністративні трибунали, попри все, $€$ міжнародними трибуналами: "The Court does not deny that the Administrative Tribunal is an international tribunal... The Courtre cognizesthat the Administrative Tribunalis a Tribunal of limited jurisdiction» ("ICJ Reports", 1956).

Отже, норми внутрішнього права міжнародних організацій виходять за межі як внутрішньодержавного, так і міжнародного публічного права та, в силу своєї юридичної природи, формують самостійну галузь у межах міжнародного права.

Підсумовуючи вищенаведені аргументи та аналізуючи праці вчених, ми бачимо, що наразі відсутня ідейна єдність та монолітність думок науковців навіть щодо предмета визначення поняття внутрішнього права міжнародних організацій. Це спричиняє безліч суперечок, адже всі концепції та підходи мають як переваги, так і недоліки. Однак наразі можемо стверджувати, що у найближчому майбутньому можливим $\epsilon$ виникнення нової парадигми розвитку цього питання в доктрині.

Правила процедури міжнародних організацій на прикладі ЮНЕСКО

Правила процедури міжнародних організацій $€$ одним 3 найважливіших аспектів внутрішнього права, що охоплює широке коло питань. Правила процедури регулюють порядок роботи органів, прийняття рішень, голосування та інші процедури, що стосуються безпосереднього функціонування іï органів, а також регламентують структуру та компетенцію допоміжних органів.

Так, Р. Мартірос'янц визначає правила процедури як «сукупність принципів і норм, що регулюють порядок організації та функціонування іï органів, а також форми та методи прийняття рішень у межах тієї чи іншої міжнародної організації» (Martirosiants, 2004). Як зазначалося вище, організація уповноважена ухвалювати власні правила процедури на підставі статуту як самостійний суб'єкт міжнародного права. Водночас І.Деттер зауважує, що «якщо статут міжнародної організації не містить прямої заборони на прийняття правил процедури, вона має право діяти на власний розсуд» (Detter, 1995). Організація не зможе існувати без правил процедури. Вмістити такий обсяг норм в статут неможливо, тож за відсутності заборони, 
організація має право діяти в межах досягнення цілей організації.

Правила процедури приймають водночас зі статутом організації. Логічним $€$ той факт, що за умови наділення організації такою компетенцією, як прийняття подібних норм, вона залишає за собою і право на їх скасування та перегляд. Однак, ситуацію дещо ускладнено, коли йдеться про норми такого характеру, що містяться в установчих документах. Процедура перегляду подібних актів $є$ дуже складною, та на практиці може не відбутися взагалі, оскільки вимагає ратифікації, як і будь-які інші зміни, що вносяться до такого договору. Це є однією з причин, чому держави в установчому акті переважно визначають основні органи організації та делегують їм повноваження для прийняття власних правил процедури. Хоча, з огляду на значущість таких правил, які $€$ основними, після статуту, актами, навіть перегляд правил процедури має дещо складний характер: так, для перегляду правил процедури Генеральної Конференції ЮНЕСКО спочатку Виконавча Рада розглядає проєкт поправок, потім Юридичний комітет і власне Генеральна Конференція.

Таким чином, статті IV.D.10. та V.B.8. Статуту ЮНЕСКО наділяють Генеральну Конференцію та Виконавчу Раду правом самостійно приймати свої правила процедури, згідно з якими вони, а також їхні комітети та комісії, функціонують.

Правила процедури Генеральної Конфреренції

Правила процедури Генеральної Конференції було прийнято на 3-й сесії 1948 року, однак майже на кожній подальшій сесії їх переглядали. Загалом 114 статей та 2 додатки, присвячені найважливішим питанням функціонування органу, а саме: порядку проведення сесій, організації Конференції, її комітетам та комісіям, обов'язкам та порядку призначення Генерального Директора, Секретаріатові, порядку здійснення голосування, прийому нових членів, застосуванню мов, виборам членів Виконавчої Ради, порядку внесення змін до Статуту, порядку денному та іншим важливим питанням.

Порядок проведення чергових і позачергових сесій Генеральної Конференції регламентовано cт. IV.D.9. Статуту та статтями 1, 5 її Правил процедури. Чергові сесії скликають один раз на два роки, а місце проведення кожної наступної чергової сесії встановлюється на попередній. Позачергові сесії скликає Генеральна Конференція за ії власним рішенням, рішенням Виконавчої Ради або на вимогу не менш ніж однієї третини держав-членів та зазвичай проводяться в штаб-квартирі ЮНЕСКО у Парижі. Також правила процедури Генеральної Конференції визначають повноваження й інших органів ЮНЕСКО: Виконавча Рада відповідає за підготовку порядку денного чергової сесії
Генеральної Конференції (ст. 9); Секретаріат під керівництвом Генерального Директора приймає, перекладає, розповсюджує та зберігає в архівах документи, доповіді та резолюції Генеральної Конференції, забезпечує усним перекладом під час засідань, а також виконує будь-яку іншу роботу, яку їй може доручити Генеральна Конференція (ст. 49).

Правила процедури також регламентують склад делегацій у кількості не більш як п'яти членів від держави-члена та члена-співробітника (ст. 21), які й собі мають бути наділені повноваженнями головою держави, головою уряду чи міністром закордонних справ, або, за визначених обставин, іншим компетентним міністром (ст. 23).

Одним із дуже важливих питань, функціонування яких забезпечено правилами процедури, $\epsilon$ безпосередньо регламентація та санкціонування діяльності комітетів і комісій. Так, ст. 32, 33 регламентують діяльність Комітету 3 перевірки повноважень, що перевіряє повноваження делегацій держав-членів та членів-співробітників, представників ООН та спостерігачів від держав, що не є членами Організації.

Комітет з кандидатур складається з очільників делегацій, що мають право голосу на Конференції. Це підкреслює його важливість, оскільки саме Комітет виконує такі адміністративні функції, як складання списків кандидатів на посаду Голови Генеральної конференції та його заступників. Також, хоча $є$ статті, що регламентують діяльність Комітетів й наділяють останніх правом самостійно обирати Голову, саме Комітет з кандидатур може пропонувати кандидатів на посаду голови та його заступників таких комітетів, комісій та інших органів Конфреренції (ст. 34, 35)

Водночас Ю. Сарвіро зазначає, що важливість цього комітету, поміж іншого, має велике значення саме з політичного огляду (Sarviro, 2009).

Можна окреслити особливе значення Юридичного комітету для втілення цілей Організації, адже саме він розглядає проєкти внесення змін до Статуту організації та правил процедури, а також може надавати тлумачення статей Статуту та рекомендувати Конференції запросити консультативне заключення Міжнародного Суду стосовно будь-якого питання щодо тлумачення Статуту. Важливість Юридичного комітету не обмежено лише питаннями, пов'язаними зі Статутом: він також розглядає інші юридичні питання, що передаються Комітету Генеральною конференцією або іншим її органом. Не є дивним той факт, що будь-якому питанню, яке безпосередньо стосується Статуту організації, приділяється так багато уваги, оскільки, як зазначалося раніше, будь-які зміни, що вносяться до Статуту, будуть підлягати ратифікації. 
Комітет зі Штаб-квартири складається 3 24 членів, яких обирають строком на 4 роки. Він виконує переважно координаційні функції: регулює політику управління Штаб-квартирою Організації та надає відповідні рекомендації Генеральному Директорові. Отже, ми бачимо, що саме комітети відповідальні за більшість організаційних питань.

Правила процедури визначають робочі та офріційні мови Конференції (ст. 50 та ст. 54). Робочими мовами Конференції $€$ англійська, арабська, французька, китайська, російська та іспанська мови. Варто зазначити, що делегати можуть презентувати свої промови й іншими мовами, але тоді саме вони, а не Секретаріат, забезпечують усний переклад таких доповідей на одну з робочих мов. Список офіційних мов дещо ширший: він також включає хінді, португальську та італійську мови. Будь-які зміни, що вносяться до Статуту, а також постанови Конференції, що стосуються Статуту та правового статусу ЮНЕСКО перекладають на всі офіційні мови. Також будь-яка делегація може вимагати перекладу інших важливих документів на офріційні мови, за умови, що така делегація самостійно надає необхідних перекладачів.

Розділ XVII регламентує порядок вступу нових членів до Організації. Держави - члени $\mathrm{OOH}$ можуть безперешкодно вступити до ЮНЕСКО, відповідно до процедури, передбаченій у статті XV Статуту. Правило 98 регламентує порядок вступу до Організації для держав, які не є членами ООН. Такі держави подають відповідну заяву Генеральному Директорові, яку потім розглядає Виконавча Рада, яка, й сама надає рекомендації Генеральній Конференції із зазначеного питання.

На думку Ю. Сарвіро, держави-члени таким чином гарантували участь усіх органів ЮНЕСКО у прийнятті таких важливих рішень. Також вона справедливо визначає особливе значення Додатку 2, що встановлює процедуру вибору членів до Виконавчої Ради. Саме цей документ визначає кількість регіональних груп, країни, що в них входять, та кількість місць, що надається представникам кожної з груп в Раді. Кількість місць напряму залежить від кількості держав, що до неї входять. Згаданий автор також зазначає, що 3 огляду на те, що держави самостійно вирішують, чи бажають вони взяти участь у наступних чергових виборах, вони на практиці домовляються в межах регіональної групи хто посяде місце у Виконавчій Раді (Sarviro, 2009).

Правила процедури Виконавчої Ради

Виконавча рада прийняла власні правила процедури 1952 року. Станом на 2019 рік - це 67 правил, об'єднаних у 13 розділів, та додаток, котрі регулюють порядок проведення сесій, зміст порядку денного, склад органу, повноваження
Голови, роботу комісій і комітетів та інші важливі питання.

Згідно з правилами процедури та Статутом, Виконавча Рада збирається не менш як 4 рази на 2 роки в період між сесіями Генеральної конференції. Як і в ситуації з Генеральною конференцією, місце проведення наступної сесії визначається на попередній, однак на практиці найчастіше вони проходять в Штаб-квартирі Організації в Парижі. Також Голова може скликати позачергові сесії за власної ініціативи або на вимогу 6 держав-членів.

Так, Ю. Сарвіро акцентує на тому, що «попри той факт, що правило 5 закріплює обов'язок Голови Ради складати порядок денний, на практиці цю фрункцію виконує Секретаріат ЮНЕСКО, в якому створені спеціальні підрозділи, що забезпечують ефективну роботу як Генеральної конференції, так і Виконавчої ради» (Sarviro, 2009).

Правило 9 визначає склад Виконавчої ради на підставі статті V.A.1.

Таким чином, Виконавча рада складається 3 58 держав-членів, яких обирає Генеральна конференція. Кожна держава-член призначає свого представника та його заступників. У процесі призначення такого представника держави-члени мусять прагнути призначити особу «компетентну в одній чи більше сорерах компетенції ЮНЕСКО». Члени Виконавчої ради обирають шляхом таємного голосування зі свого складу Голову Ради та шість його заступників строком на 2 роки до наступної сесії Генеральної конференції.

Одразу ж після вибору нових членів Ради, на кожній черговій сесії Генеральної конференції Рада встановлює склад комітетів і комісій, необхідних для її ефективного функціонування. До таких комісій належать: Комісія з фінансових та адміністративних питань, Комісія 3 програм та зовнішніх зв'язків, Спеціальний комітет, Комітет 3 конвенцій та рекомендацій і Комітет 3 неурядових партнерів. Також Рада залишає за собою право в разі необхідності створювати тимчасові допоміжні органи.

Правила процедури Виконавчої ради, на думку Ю. Сарвіро, багато в чому схожі 3 правилами процедури Генеральної конференції. Так, наприклад, правила, що стосуються проведення засідань, майже збігаються (порядок виступів, голосування, публічність проведення засідань). Утім існують й певні розбіжності. Наприклад, на відміну від правил процедури Генеральної конференції, правила Виконавчої ради не називають такої категорії мов, як «офріційні». Правило 21 лише називає категорію «робочих мов», що повністю збігається 3 робочими мовами Конференції. Також вона зауважує, що XII розділ визначає добові витрати членів Ради під час виконання службових 
обов'язків такими, що на себе бере Організація (Sarviro, 2009). Цілком погоджуємося з тим, що це $\epsilon$ дуже важливим правилом і нормою, що дозволяє урівняти держав-членів для втілення цілей Організації, оскільки для держав, що розвиваються, витрати на відрядження її представників у Парижі протягом двох років можуть бути серйозною статтею витрат.

\section{Наукова новизна}

Автори досліджують і зіставляють ключові питання та доктринальні підходи до визначення поняття юридичної природи та інших питань стосовно внутрішнього права міжнародних організацій, демонструючи особливості й тонкощі такої проблематики на прикладі Організації Об'єднаних Націй з питань освіти, науки та культури (ЮНЕСКО).

\section{Висновки}

Висвітливши ключові питання в контексті розуміння поняття та сутності такого феномену як внутрішнє право міжнародної організації, слід зробити такі висновки: внутрішне право міжнародних організацій можна розглядати як систему юридичних норм, що приймають органи міжнародної організації на підставі її статуту й виражають її волю, та які покликані регулювати внутрішні відносини організації для забезпечення iii ефективного функціонування. Попри безліч суперечок навколо питання щодо місця внутрішнього права організацій в системі міжнародного права, внутрішнє право не є частиною внутрішньодержавного чи міжнародного публічного права, а є частиною міжнародного права в широкому сенсі цього поняття.Не погоджуємося з науковцями, які розглядають внутрішнє право у вузькому сенсі та не відносять установчі акти до його джерел.

Внутрішній правопорядок ЮНЕСКО має складну та багаторівневу структуру, що забезпечує ефективну діяльність Організації. Правила процедури постійно переглядаються та підлягають змінам, що дозволяє Організації ефективно справлятися із завданнями, які на неї покладають держави-члени. Структура побудована таким чином, аби уникнути зайвого бюрократизму, забезпечити прозорість діяльності, уникнути корупції та не марнувати найважливіший ресурс - час. Особливу увагу приділяють виключно тим питанням, що цього потребують (як, наприклад, внесення змін до Статуту).

Усі правила ЮНЕСКО ухвалюються на підставі Статуту, і вони не тільки створюють нові норми, але й доповнюють чинні.

\section{REFERENCES}

Chernichenko, S.V. (1971). Iuridicheskaia priroda vnutrennego prava mezndunarodnykh organizatsiy [The legal nature of the domestic law of international organizations]. Moscow [in Russian].

Detter, I. (1995). Law making of international organizations. Stockholm.

ICJ Reports (1956). www.icj-cij.org. Retrieved from https://www.icj-cij.org/files/case-related/30/030-19561023-ADV-0100-EN.pdf.

Kaminska, N., Loshchykhin, O., \& Romanova, N. (2019). The role of the OSCE in ensuring gender equality into policies and practices. Fundamental and Applied Researches in Practice of Leading Scientific Schools, 34(4), 87-91. Retrieved from https://farplss.org/index.php /journal/article/view/662.doi:10.33531/farplss.2019.

Kaminska, N., Shpakovich, O., \&Demidenko, V. (2018). Trends in the Development of International Legal Personality and Subjects of International Law: Theoretical Analysis. OPCION. Universidad del Zulia, 87-2(34), 507-520. Retrieved from https://www.scopus.com/record/display.uri?eid=2s2.085060494215\&origin=resultslist\&sort=plff\&src=s\&st1=Trends+in+t he+development+of+international+legal+personality\%3a+theoretical+analysis\&st2=\&sid=ad6638de79b74eed02483ba bfeecc362\&sot=b\&sdt=b\&sl=97\&s=TITLEABSKEY\%28Trends+in+the+development+of+international+legal+personalit y\%3a+theoretical+analysis\%29\&relpos=0\&citeCnt=0\&searchTerm $=$.

Kaminskaia, N.V. (2014). Vliianie globalizatsionnykh tendentsiy nastanovlenie regionalnykh pravovykh sistem [Influence of globalization tendencies on formation of regional legalsystems]. Mezndunarodnoe pravo, International law, 2, 20-33. doi: 10.7256/2306-899.2014.2.10941 [in Russian].

Lukashuk, I.I. (2005). Mezndunarodnoe pravo. Osobennaia chast [International law. Special part]. Moscow: Volters Kluver [in Russian].

Margiev, V.I. (1999). Vnutrennee pravo mezndunarodnykh orhanizatsiy [Domestic law of international organizations]. Extended abstract of Doctor's thesis. Kazan [in Russian].

Martirosiants, R.E. (2004). Pravila protsedury kak vyraznenie sobstvennoy iuridicheskoy voli mezngosudarstvennykh organizatsiy]. Extended abstract of candidate's thesis. SPb. [in Russian].

Moravetskiy, V. (1976). Funktsii mezndunarodnykh organizatsiy [Functions of international organizations]. Moscow [in Russian].

Morozov, G.I. (1972). O prave mezndunarodnykh organizatsiy [On the law of international organizations]. Sovetskoe gosudarstvo i pravo, Soviet state and law, 56 [in Russian].

Pravila protsedury Generalnoy Konferentsii IUNESKO [Rules of procedure of the General Conference]. (2018). www.un.org. Retrieved from https://www.un.org/ru/documents/rules/unesco.pdf [in Russian].

Pravila protsedury ispolnitelnogo Soveta IUNESKO [Rules of procedure of the Executive Board]. (2018). unesdoc.unesco.org. Retrieved from https://unesdoc.unesco.org/ark:/48223/pf0000261592_rus [in Russian]. 
Proniuk, N.V. (2010). Suchasne mizhnarodne pravo [Modern international law]. Kyiv: KNT [in Ukrainian].

Sarviro, lu.A. (2009). Vnutrennee pravo mezndunarodnykh orhanizatsiy (naprimere UNESKO) [Domestic law of international organizations (on the example of UNESCO)]. Extended abstract of candidate's thesis. Moscow [in Russian].

Shibaeva, E.A., \& Potochnyy, M. (1988). Pravovye voprosy struktury i deiatelnosti mezndunarodnykh organizatsiy [Legal issues of the structure and activities of international organizations] ( $2^{\text {nd }}$ ed.). Moscow: MGU [in Russian].

Shpakovych, O., \& Shalamberidze, M. (2020). Pravotvorcha diialnist mizhnarodnykh orhanizatsii [Law-making by international organizations]. Naukovyi visnyk Natsionalnoi akademii vnutrishnikh sprav, Scientific Herald of the National Academy of Internal Affairs, 3(116), 108-114. doi: https://doi.org/10.33270/01201163.108 [in Ukrainian].

Shpakovych, O.M. (2020). Pravomizhnarodnykh orhanizatsii [Law of international organizations]. Kyiv [in Ukrainian].

Tribunal administratif. (1929). Jugement, 2. www.ilo.org. Retrieved from https://www.ilo.org/dyn/triblex /triblexmain.fullText?p_lang=en\&p_judgment_no=.02\&p_language_code=FR.

Ustav Organizatsii Obedinennykh Natsiy po voprosam obrazovaniia, nauki i kultury: mezndunar. dok. ot 16 noiab. $1945 \mathrm{~g}$. [Constitution of the United Nations Educational, Scientific and Cultural Organization from November 16, 1945]. (n.d.) .zakon.rada.gov.ua. Retrieved from https://zakon.rada.gov.ua/laws/show/995_014 [in Russian].

Voitsikhovskyi, A.V. (2020). Mizhnarodne pravo [International law]. Kharkiv: KhNUVS [in Ukrainian].

\section{СПИСОК ВИКОРИСТАНИХ ДЖЕРЕЛ}

Черниченко С. В. Юридическая природа внутреннего права международных организаций. М., 1971. С. 216.

Detter I. Law making of international organizations. Stockholm, 1995. P. 47-48.

ICJ Reports, 1956. P. 97. URL: https://www.icj-cij.org/files/case-related/30/030-19561023-ADV-01-00-EN.pdf.

Kaminska N., Loshchykhin O., Romanova N. The role of the OSCE in ensuring gender equality into policies and practices.Fundamental and Applied Researches in Practice of Leading Scientific Schools. 2019. No. 34 (4). P.87-91. URL: https://farplss.org/index.php/journal/article/view/662. doi: 10.33531/farplss.2019.

Kaminska N., Shpakovich O., Demidenko V. Trends in the Development of International Legal Personality and Subjects of International Law: Theoretical Analysis. OPCION. Universidad del Zulia. 2018. Vol. 34. No. 87-2. P. 507-520. URL: ttps://www.scopus.com/record/display.uri?eid=2s2.085060494215\&origin=resultslist\&sort $=$ plff $\&$ src $=s \& s t 1=$ Trends+in+the+development+of+international+legal+personality\%3a+theoretical+analysis \&st2= \&sid=ad6638de79b74eed02483babfeecc362\&sot=b\&sdt=b\&sl=97\&s=TITLEABSKEY\%28Trends+in+the+develop ment+of+international+legal+personality\%3a+theoretical+analysis\%29\&relpos=0\&citeCnt=0\&searchTerm=.

Каминская Н.В. Влияние глобализационных тенденций на становление региональных правовых систем. Международное право. 2014. № 2. С. 20-33. doi: 10.7256/2306-899.2014.2.10941.

Лукашук И. И. Международное право. Особенная часть : учебник. М. : Волтерс Клувер, 2005. 511 с.

Маргиев В. И. Внутреннее право международных организаций : автореф. дис. ... д-ра юрид. наук: 12.00 .10$. Казань, 1999. 282 с.

Мартиросьянц Р.Э. Правила процедуры как выражение собственной юридической воли межгосударственных организаций : автореф. дис. ... канд. юрид. наук : 12.00.10. СПб., 2004. 195 с.

Моравецкий В. Функции международных организаций. М., 1976. С. 164.

Морозов Г. И. О праве международных организаций. Советское государство и право. 1972. С. 56.

Правила процедуры Генеральной Конференции ЮНЕСКО. 2018. URL: https://www.un.org/ru/documents/ rules/unesco.pdf.

Правила процедуры Исполнительного Совета ЮНЕСКО. 2018. URL: https://unesdoc.unesco.org/ark:/ 48223/pf0000261592_rus.

Пронюк Н. В. Сучасне міжнародне право : навч. посіб. Київ : КНТ, 2010. 280 с.

СарвироЮ.А. Внутреннее право международных организаций (на примере ЮНЕСКО): автореф. дис.... канд.юрид.наук : 12.00.10. М., 2009. 188 с.

Шибаева Е. А., Поточный М. Правовые вопросы структуры и деятельности международных организаций : учеб. пособие. 2-е изд. М. : МГУ, 1988. 168 с.

Шпакович О., Шаламберідзе М. Правотворча діяльність міжнародних організацій. Науковий вісник Національної академії внутрішніх справ. 2020. № 3 (116). С. 108-114. doi: https://doi.org/10.33270/ 01201163.108.

Шпакович. О. М. Право міжнародних організацій : курс лекцій. Київ, 2020. 121 с.

Tribunal administratif. Jugement No.2. 15 Janvier 1929. URL: https://www.ilo.org/dyn/triblex/ triblexmain.fullText?p_lang=en\&p_judgment_no=.02\&p_language_code=FR.

Устав Организации Объединенных Наций по вопросам образования, науки и культуры : междунар.док.от 16 нояб. 1945 г. URL: https://zakon.rada.gov.ua/laws/show/995_014.

Войціховський А. В. Міжнародне право : підручник. Харків : ХНУВС, 2020. 544 с.

Стаття надійшла до редколегії 07.09.2020 
Shpakovych O. - Doctor of Law, Professor, Professor of the Department of Comparative and European Law of the Institute of International Relations of the Taras Shevchenko National University, Kyiv, Ukraine ORCID: https://orcid.org/0000-0002-1080-4817;

Kahramanian D. - Student of the Department of International Law of the Institute of International Relations of the Taras Shevchenko National University, Kyiv, Ukraine

ORCID: https://orcid.org/0000-0002-5253-128X

\section{Internal Law of International Organizations}

The purpose of the article is to analyze existing research on the internal law of international organizations, and to define the concept, legal nature, place of internal law of international organizations in international law on the example of the internal law of United Nations Educational, Scientific, and Cultural Organization (UNESCO). The methodological basis of the study is composed of, inter alia, comparative-legal, systemic and historical methods of scientific knowledge. Scientific novelty. The authors examine and compare key issues and doctrinal approaches to the definition, legal nature and other issues related to the internal law of international organizations, demonstrating the features and subtleties of this issue on the example of the United Nations Educational, Scientific and Cultural Organization (UNESCO). Conclusions. Having highlighted the key issues in the context of understanding the concept and essence of such a phenomenon as the internal law of international organizations, the following conclusions can be drawn: internal law of international organizations can be considered as a system of legal rules adopted by the organs of international organization on the basis of its statute to ensure its effective functioning. Despite much controversy over the place of internal law of international organizations in the system of international law, internal law is not part of domestic or public international law, but is part of international law in the broadest sense of the term. We do not agree with scholars who consider internal law in the narrow sense and do not refer the constituent acts to its sources.

Keywords: international organizations; internal law of international organizations; internal law of UNESCO; rules of procedure of UNESCO; law of international organizations. 